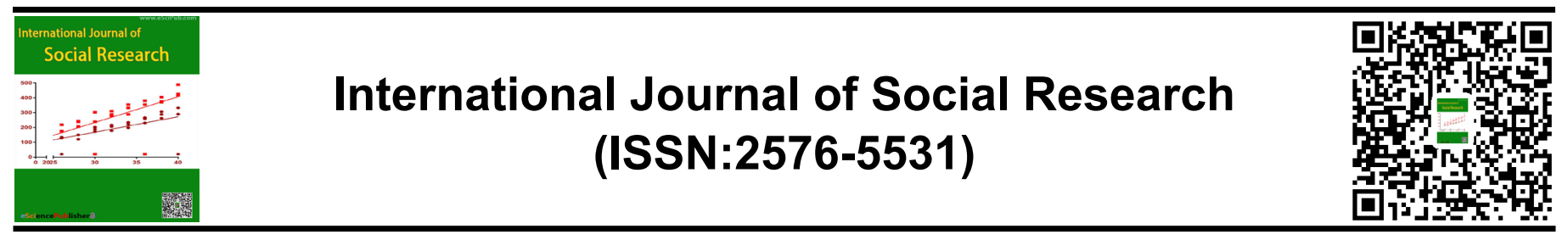

\title{
IMPACT OF CULTURAL EVENTS ON THE CITY AND CULTURAL TOURISM DEVELOPMENT IN IT
}

\section{Prof. Dr. Virginija Jurènienè, MA Aurelija Kuizinaitè}

Institute of Social Sciences and Applied Informatics, Vilnius University Kaunas Faculty

\begin{abstract}
A feature of the modern society is the city which tries to express itself by means of social and physical environment. One of the tators by means of smart global technologies. Cultural activities Kaunas Faculty manifest by implementing cultural projects of various areas, starting from one-time local events, and ending with large-scale international projects. Cultural tourism is a great opportunity of urban and regional tourism development. Implementation of cultural events in cities can have impact on cultural tourism development and its planning, and can be one of the very important economic as well as sociocultural impact of tourism that manifests by created infrastructure, increasing supply of services and entertainment, and lively cultural life in cities. The work is relevant because it reveals for the first time how mega cultural events in cities are or can be an effect for cultural tourism development in cities.
\end{abstract} ${ }^{*}$ Correspondence to Author: means of expression are events whose activities engage local Institute of Social Sciences and Apresidents, visitors, guests, tourists, and, of course, distant spec- plied Informatics, Vilnius University

Keywords: cultural events, city, types of impact, cultural tourism.

How to cite this article:

Virginija Jurènienè, Aurelija Kuizinaitè. IMPACT OF CULTURAL EVENTS ON THE CITY AND CULTURAL TOURISM DEVELOPMENT IN IT. International Journal of Social Research, 2020; 4:47. 


\section{INTRODUCTION}

A city is a space where people not only live, acquire new skills, gain experience, but also acquire a respective identity (Budžienè 2011:106). In today's modern society, it is not enough for a person to be proud of a developed infrastructure only. Residents relate the city's uniqueness, identity and exclusivity with the city's image that has impact on not only attracting new residents, but also tourists, attracting investments, cooperation and partnership with other cities.

Every city is exceptional in its traditions, values and geographical local, which creates a special aura of that city. These factors form the city's culture and, partially, its development. Urban culture is concentrated in popular city spaces liked by residents such as city squares, parks, halls and so on. It is often understood as a system of other social actions (ideals, language, myths, customs) or values that reflect the development of the system of evolution. In all of this chain of actions, urban culture and cultural tourism are also included into urban image, and it is related to not only historical personalities, architectural monuments, but also cultural and entertainment events. Urban entertainment and cultural life is an inseparable part of the daily culture that helps the city to shape its identity and significance as well as create its image. This is why each city wants and desires such events as global fairs, exhibitions, international sports events or festivals. Even without such events, a city participates in international competitions and aims at winning and becoming a "capital of culture" because such international projects can help the city to improve its image, create new infrastructure, improve its economy, and attract tourists.

Being a "capital of culture and entertainment", a city has an image that often connects more than one area of activity. On the one hand, this can include the result created and obtained by local businesses; on the other hand, this can be successful and effective business, in which case the supply of entertainment and events in a particular city improves and strengthens urban image, and concentration in the centre of the city serves not only for local businesses, but also tourists (Budžienè 2011:108).

Cultural events are an inseparable part that provides a city with energy; moreover, cities that organise and implement cultural events are noticed as innovative, shifting, attractive and encouraging engagement of not only the local community, but also guests and tourists into consumption through events, thus revealing local exclusivity, authenticity and originality. Furthermore, the developed connection between culture and a city can help to strengthen urban image, whereas city residents can have a sense of pride.

Problem of the article: What impact do cultural events have on the city and cultural tourism development?

Aim of the article: to analyse the impact of cultural events on the city and cultural tourism development.

Methods: scientific comparative analysis, qualitative research.

\section{Types of impact of known events on the city and their features}

Events have many positive and negative consequences for a city and interested parties. In order to determine and forecast the impacts, it is primarily necessary to find out what features are attributed to different impacts.

Impact can be measured by evaluating the results of certain actions that determine the relations between cause and effect. Impact can be evaluated from a certain impact category to the positive and negative features it creates. One of the examples could be when impact fluctuates from social damage to benefit in the social context. In scientific literature, impact is described differently; however, it should be emphasised that impact is a process that has different foundations, influences various areas (economic, social, etc.), and is characteristic of different ways of operation (direct and indirect). Therefore, in order to understand the essence of 
impact, it is necessary to understand all of its dimensions because the concept of impact itself changes when these dimensions change. The most important dimension of the concept of impact is "impact on something": a person, an organisation, a community or, for instance, a country (Jurènienè, Urbonienè 2018:124-125). It is also important that impact can be direct and indirect. Moreover, it is important to note that, for instance, direct impact on a person can be treated as indirect impact on the community which the person is a member of. Impact is also important when evaluating the dimension of time, i.e., short-term or long-term (Jurèniené, Urbonienè 2018:125).

Ritchie distinguishes the types of impact of known events on the city or region and their features. The following six impacts of cultural events are distinguished: economic, tourism or commercial, psychological, sociocultural, and political (Ritchie 1984:4) (Table 1).

\section{Table 1 Types of impact of known events on the city or region as well as their impact}

\begin{tabular}{|c|c|c|}
\hline \multirow[t]{2}{*}{ Type of impact } & \multicolumn{2}{|l|}{ Impact } \\
\hline & Positive & Negative \\
\hline Economic & $\begin{array}{l}\text { Increased return } \\
\text { Establishment of new jobs. }\end{array}$ & $\begin{array}{l}\text { Increase in prices during an event. } \\
\text { Real estate speculations. }\end{array}$ \\
\hline $\begin{array}{l}\text { Tourism and hospitality / } \\
\text { Commercial }\end{array}$ & $\begin{array}{l}\text { Increased popularity of a city as a tourist } \\
\text { location. } \\
\text { Increased popularity of the opportunities } \\
\text { for regional investment and commercial } \\
\text { activities. }\end{array}$ & $\begin{array}{l}\text { Acquiring negative reputation for false } \\
\text { activities and conditions that increase } \\
\text { requirements. } \\
\text { Opposing reaction of local companies } \\
\text { due to potential competition. }\end{array}$ \\
\hline Physical & $\begin{array}{l}\text { Construction of new infrastructure. } \\
\text { Improvement of current infrastructure. }\end{array}$ & $\begin{array}{l}\text { Damage to the environment. } \\
\text { Too large flows of people. }\end{array}$ \\
\hline Sociocultural & $\begin{array}{l}\text { Increased interest and participation of } \\
\text { local residents in event-related activities. } \\
\text { Strengthening of regional traditions and } \\
\text { values. }\end{array}$ & $\begin{array}{l}\text { Commercialisation of an event. } \\
\text { Changing the main idea of the event in } \\
\text { order to adapt to tourism goals. }\end{array}$ \\
\hline Psychological & $\begin{array}{l}\text { Improved sense of pride and community of } \\
\text { local residents. } \\
\text { Increased interest in non-local cultures. }\end{array}$ & $\begin{array}{l}\text { Tendency of the host region to take the } \\
\text { "defensive" position. } \\
\text { Possibility of misunderstandings } \\
\text { between local residents and comers that } \\
\text { creates mutual hostility. }\end{array}$ \\
\hline Political & $\begin{array}{l}\text { International acknowledgement of the } \\
\text { region and its values. } \\
\text { Dispersion of political values of the state } \\
\text { and residents. }\end{array}$ & $\begin{array}{l}\text { Satisfaction of the political elite's } \\
\text { ambitions using local residents. } \\
\text { Distortion of the main idea of the event in } \\
\text { order to express the values of existing } \\
\text { political system. }\end{array}$ \\
\hline
\end{tabular}

Source: Ritchie, J. R. (1984). Assessing the Impact of Hallmark Events: Conceptual and Research Issues. In Journal of Travel Research, p. 4

When analysing the features of cultural events on the city, it is important to note that their exclusive quality is the duality of impact evaluation. On the one hand, a certain phenomenon can be evaluated positively as beneficial for society. On the other hand, the same impact can be treated as violation of social norms and be completely unacceptable. One of 
the examples such as a festival can be evaluated positively because it can bring economic benefit by attracting local visitors, tourists; however, it can also be evaluated negatively because it requires higher expenses to maintain the environment, expenses for police, and the risk of crimes, traffic, air pollution and noise increases (Maughan, Bianchini 2004).

Economic benefit is evaluated by calculating the expenses of a certain cultural event and the income from it; therefore, this impact receives a lot of attention and is studied the most. It often happens that events are evaluated based only on their economic index and emphasising only the positive changes created by them (Richards, Wilson 2004). Moreover, establishment of new jobs can be noticed along with increased return. Also, expenses are measured and the way tourists travel as well as the number of flows are determined. These impacts are important and depend on the success of the event; however, in order to achieve correct impact evaluation, it is important to remember the negative consequences such as speculations in the real estate market and rising of the prices for services. (Ritchie, 1984)

Impacts of tourism and commercial impacts. One of the impacts is emergence and popularity of a locality as a tourism destination and a niche for investments. Of course, if a cultural event is unsuccessful, the region can acquire negative reputation. However, popularity brings interest in any case and attracts not only potential visitors, but also investors. On the other hand, establishment of new companies can create a negative response of local businesses, and they will start sensing competition (Skoultsos, Tsartas 2009:297).

Physical impact. This is the third type of impact that determines changes in the urban environment. This type of impact requires a lot of time and expenses because it is inevitable when organising bigger events. These changes are often accompanied by conflict that arises because of unpredictable development benefit and potential damage for the environment due to ongoing constructions and their further employment. However, there is no one unified solution to solve these arising conflicts. Every city must responsibly and respectively evaluate both positive and negative sides and create development plans, unique economic conditions, natural resources and ways for local residents' value employment and expression (Ritchie, 1984).

Ones of the positive examples include new construction objects related to the event; also, improvement works for existing infrastructure that would not receive funding or political support if it were not for the big events. Obviously, these infrastructures are later left to use for the residents. General use structures such as road systems or unique constructions will remind of a certain event. A negative consequence of the physical impact is pollution to the environment when preparing for a certain event. Furthermore, there is a risk that the infrastructure works can exceed residents' expectations or not meet them at all. Another negative side can be too heavy flows of people that create inconveniences for local residents by put weight on the field of services. However, with regard to the negative impacts, there are also positive consequences when physical impacts of events improve a region's cultural life and economy. Society is also happy with the construction results that have been encouraged by the physical impact of cultural events, and are proud of their aesthetic benefits and their operation for long years. One of the most noticeable advantages of impact is restoration of degrades regions or urban districts encouraged by a certain cultural event (Smith, Fox 2007).

Sociocultural impact. This impact receives more and more attention, and the main goals of popular events are usually development of social interactions by expressing interest, the system of values and traditions of local residents.

Sociocultural impact can also have both positive and negative effects. Positive effect includes the following characteristics: promotion of cultural 
and social development. Residents' engagement on the social level is possible, for instance, integration of volunteers into the preparation activities for the event. Another direction of positive social development deal with certain activities that have a positive effect on the society and encourage its well-being. It can be noted that there is a higher interested in culture within the society after cultural events. (Maughan, Bianchini 2004). International cultural events especially help to create opportunities for cultural development and nurturing, and they expand the society's outlooks. Cultural events promote various activities, attract cultural and popular personalities, and create demands that do not arise in the society under usual conditions. Thus, the catalysts of renewal can include such cultural events.

However, negative consequences of impact are inevitable as well. Is very important for the event activities to reflect local residents' values. Otherwise the event may create cultural elitism and promote social conflict. An event should be accessible to the wide society or its major part and create a possibility to participate in it without any major obstacles. Such events that make attempts to increase the gap between the layer of the society are not welcome and do not create good and positive emotions for the society. Instead of creating new social and cultural indexes, event initiators and organisers must try to include existing indexes because only then can they implement the main goal of cultural events, i.e., development of the community.

Psychological impact is described as positive in the general sense; however, it is poorly understood. It is closely related to the cultural impact that has been discussed above. Its main feature is the factor of prestige (Ritchie, 1984). Prestige encourages local residents' pride in their place of residence if an event is successful. This pride can have a positive impact on residents' self-confidence and employees' working capacity. Other advantages include the following: interest of the local community in other regions and other communities. Another example is the cosmopolitan attitude of rather small and isolated towns that has developed due to popular events held in them. Of course, negative psychological consequences can be noted. For instance, constant negative comments or criticism from strangers can create conditions for doubt and taking defensive positions that bring down enthusiasm and the sense of pride in one's region. Also, in a case of a smaller community, a large flow of visitors and tourists that is characteristic of different behavioural norms and values can create conflict for both local residents and guests. Thus, event organisers should pay attention to positive and negative features of psychological impact and create foundations for patience and trust that would help to solve arising misunderstandings.

Political impact. The last category deals with political impacts that are usually ignored or unwillingly discussed publicly. However, despite the fact that political goals are usually the main factor why certain events are attributed to be prepared in certain regions only. The examples include the following: The Olympic Games, global exhibitions, sports competitions or international projects.

Political impact can be evaluated on micro and macro levels. On the macro level, the most prominent goals are implemented. Private or government institutions aim at improving the reputation of a locality for commercial or tourism reasons. Certain ideological approaches may be attempted to promote using an event. Ritchie emphasised short-term and long-term improvement of local image (Ritchie 1984). Political micro factors are less noticeable but may be more important on the political scale. This is related to individuals' desire to improve their career in the political and non-political areas by using the acquired visibility when participating in event activities. Moreover, political impact includes an opportunity for local artists or athletes to become popular or simply test their chances on the international level. It 
also includes a negative impact when the elite in the society aims at implementing their political goals and organises a certain event hiding behind social development strategy creation. In this case, politicians may try to satisfy their ambitions and change the actual essence of the event.

All the discussed impacts of cultural events and determining factors are important for a city, and each region can create its unique event that would create benefit for both the local community and inbound guests and tourists by interpreting and organising cultural activities.

Maughan and Bianchini (2005) distinguish the following benefits of cultural events:

- A way to develop cultural actions and culturally educate the audience;

- A tool to attract visitors and improve image;

- Source of creativity and innovation;

- An opportunity to contemplate and foresee further development;

- A tool to contemplate the use of various approaches to target use of localities and spaces to revive the city;

- The sphere of cooperation of the public, private and volunteer sectors that aims to renew the city or locality;

- Effective tool to develop skills and social capital;

- A way to promote intercultural cooperation and understanding;

- Opportunity for socialising and celebrating the community, as well as encouragement for local residents' originality development and their sense of pride of their place of residence;

- An important factor to develop social and economic well-being (Maughan, Bianchini 2005)

Therefore, in order for the general impact of the event on tourism development to be positive, there has to be a balance between all the types of impact. In order to achieve this, positive and negative features of the impacts have to be anticipated. Negative impact can often be determined by means of informing or intervention. Good planning is important, and success of a cultural event depends on whether the goal of an impact has been achieved and which factor of it is created for the society. Cities that organise cultural events are seen as creative, renewable, attractive and encouraging innovation.

Cultural events actively add to the social and cultural life. Events have impact on the city and thus tourism.

\section{Cultural tourism and it resources}

Cultural tourism and its resources on the international scale are one of the most important elements that form a country or a certain city's image because cultural tourism helps to know one's city better and understand the national values and history. Cultural tourism includes travels in order to watch or participate in the "fading life" that people remember (Grecevičius et al. 2002:38). Figure 1 introduces the goals of cultural tourism.

The goals of cultural tourism show that their main aim is to preserve cultural resources as the main functioning of tourism business and that it includes using cultural and historic assets for cognition, education, recreation interests and needs.

The characteristics of this type of tourism are defined by the raised exclusive goals, tangible and intangible cultural values and unique traits and needs of cultural tourists that motivate them to choose different forms of cultural tourism. Cultural tourism is a type of local and inbound tourism which is a complex sector that depends on regional culture, region-specific tourism, its resources and economy and social and other characteristics.

Cultural integration and growing economy determine tourism development in a city which is related to the impact on sociocultural 
environment, nature and economy. A locality suitable for tourism development such as local culture is a unique factor that distinguishes localities one from another and can attract tourists. This helps to recreate and preserve a country's culture. The relationship between the local community and visitors create an opportunity to increase international understanding and determines positive social change that has impact on visitors and local communities. However, there can be a negative impact that can impede regional progress and modernisation as well as condition cultural stagnation at the travel destination due to high or excessive interest of tourists in the country or locality's lifestyle. Because of the authenticity in terms of visitors and inbound tourists, there are doubts and the spirituality of the locality is lost. First of all, the impact of cultural events on tourism development should be understood as communication between nations, people and cultures (Žilinskas 2011:274, 275).

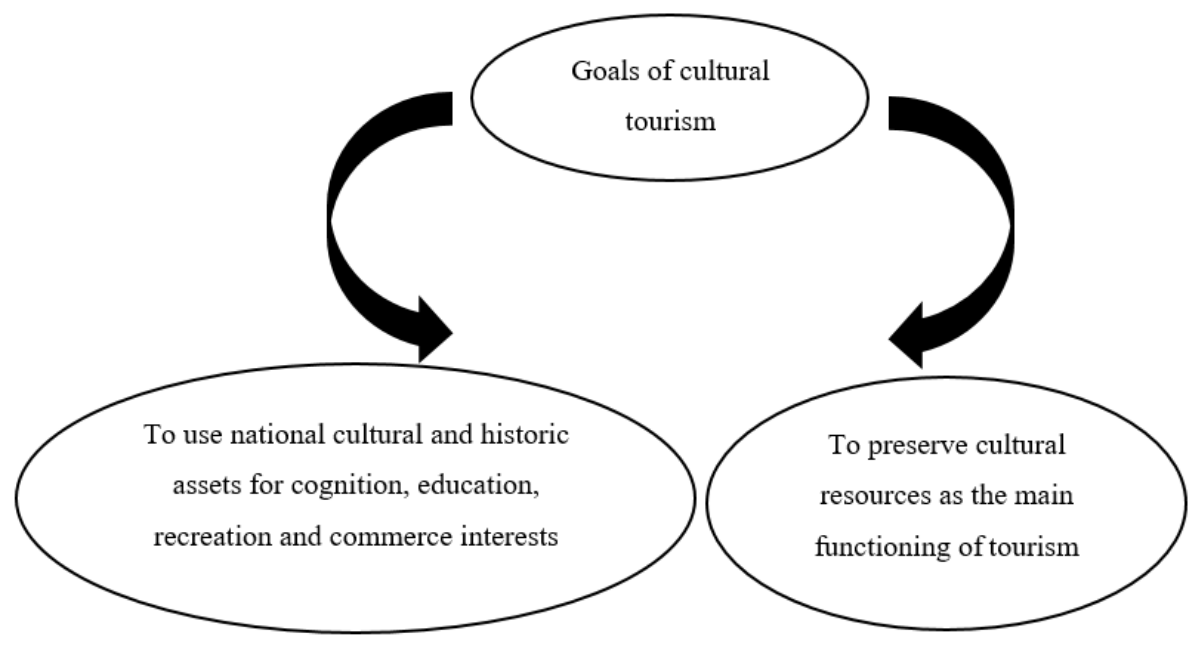

Fig. 1. Goals of cultural tourism

Source: Jurènienė V. (2009). Kultūrinis turizmas.Kultūros vadyba I. (ed. J. Svičiuliene) Vilnius: Vilnius University publishing house, p. 43

\subsection{Research strategy}

Research strategy in the context of the conception is defined as follows: all of the qualitative research traditions can generally be joined into three categories (i.e., oriented towards individual experiences, oriented towards the society and culture, and oriented towards language and communication; the following three strategies are distinguished: deep interview strategy, case study strategy, and analysis of recorded spoken events (Novelskaitè 2012:10). This study aims at revealing the impact of a cultural event on cultural tourism development planning in Kaunas city; therefore, the case study strategy was selected. This research strategy was selected because a case study as a strategy is based on the outlooks of both the researcher and the participant, points out immersion into research environment (Novelskaitė 2012:10).

\subsection{Research units and their sampling}

The sampling of qualitative study respondents is carried out by means of targeted criterion sampling because the criterion sampling method is effective as it helps to collect quality data (Bitinas et al. 2008:103). Criterion sampling is also applied when sample units are selected from the population based on the criteria determined by the researcher ((Bitinas et al. 2008:102). The following criteria were distinguished for the respondents:

- Experts who work in the cultural events sector that have higher education and international experience. 
- Persons who have higher Interested parties in this case are the city and education and an area of specialisation cultural tourism. During the study, Respondent (tourism, city municipality administration).

- Persons who have the required information.

During the research, cultural events operators (organisers, leaders), tourism specialists and a city municipality employee were interviewed.

\subsection{Attitude of interested parties towards} the impact of cultural events as a factor of cultural tourism planning

Mega cultural events usually have impact on cultural tourism and its planning in the city.

No. 3 defines as follows: "Impact can be different, for instance, positive and negative, the kind that gives or does not give benefit, or shortterm and long-term", and Expert No. 2 adds that " $<\ldots>$ impact is an action, a process that creates consequences."

In order to find out which types of impact can a cultural event have on cultural tourism planning in Kaunas city (Lithuania), the answers of the respondents are marked in different colours in Table 2.

Table 2 Types of impact Expert No. 1 - E1 Expert No. 2 - E2 Respondent No. 1 - R1 Respondent No. 2 - R2 Respondent No. 3 - R3 Respondent No. 4 - R4

\begin{tabular}{|c|c|c|c|c|c|c|}
\hline Type of impact & \multicolumn{6}{|c|}{ Choice } \\
\hline Economic & E1 & E2 & $R 1$ & $R 2$ & $R 3$ & $R 4$ \\
\hline Commercial (Tourism and hospitality sector) & E1 & E2 & $R 1$ & $R 2$ & $R 3$ & $R 4$ \\
\hline Physical (infrastructure) & E1 & E2 & $R 1$ & $R 2$ & $R 3$ & $R 4$ \\
\hline Sociocultural & E1 & E2 & $R 1$ & $R 2$ & $R 3$ & $R 4$ \\
\hline Psychological & E1 & E2 & $R 1$ & $R 2$ & $R 3$ & $R 4$ \\
\hline Political & E1 & E2 & & $R 2$ & $R 3$ & $R 4$ \\
\hline
\end{tabular}

Reviewing the results presented in the table, it can be noted that almost all of the respondents' opinion is unified. Cultural events can have economic, commercial (hospitality), physical, sociocultural and political types of impact.

Economic impact: Expert No. 1 claims that "impact in all areas will manifest but its scale depends on funding, changes in attitudes; understanding determines a lot, and on how many predicted continuation factors each evaluated activity has".

Hospitality (commercial) impact: Respondent No. 3 claims that "the sector of creative industries will flourish and undergo a period of an upsurge through the tourism and hospitality sector". Respondent No. 2 agrees and claims that "the economic factor encourages the tourism sector, business, the sectors of accommodation, entertainment, leisure, souvenirs and creative industries".

Physical (infrastructure) impact: "<...> infrastructure, for instance, the European Capital of Culture as a mega event, the title of a capital, is a very strong aspect to review the city and government's strategies in cultural infrastructure development, and I believe one can clearly see in the plan of the decision-makers such questions as construction of a concert hall, renewal of old cultural objects" (Expert No. 2).

Sociocultural impact: Respondent No. 4 says that "social impact is especially important because cultural events encourage the society's active participation in the cultural life, awaken their public spirit, interest in the city, emotional relationship with it and the neighbours". 
Psychological impact: "the psychological impact of mega events is very important" (Expert No. 2); "it is one of the least negotiable ways how a mega event influences residents' consciousness and their price in their city" (Respondent No. 1); "they feel that they belong to Europe and the European culture rather than live on some edge of Europe somewhere"'(Expert No. 1).

Political impact: for this point, Expert No. 1 and Respondents No. 1, No. 2, No. 3 and No. 4 agree that it is a very important impact of a cultural event; however, Expert No. 2 strictly opposes this type of impact because "culture should not be politicised; culture should be free, and an event such as a mega festival has a positive impact because it attracts various participants and tourists, and they thus encompass the economic, tourism and hospitality sectors through which other possible impacts such as the sociocultural or psychological impacts overlap".

Respondent No. 3 distinguishes the impacts created by a cultural event according to their strength in cultural tourism (Fig. 2):

$\begin{array}{lll}\text { No impact } & \text { Average impact } & \text { Strong impact }\end{array}$

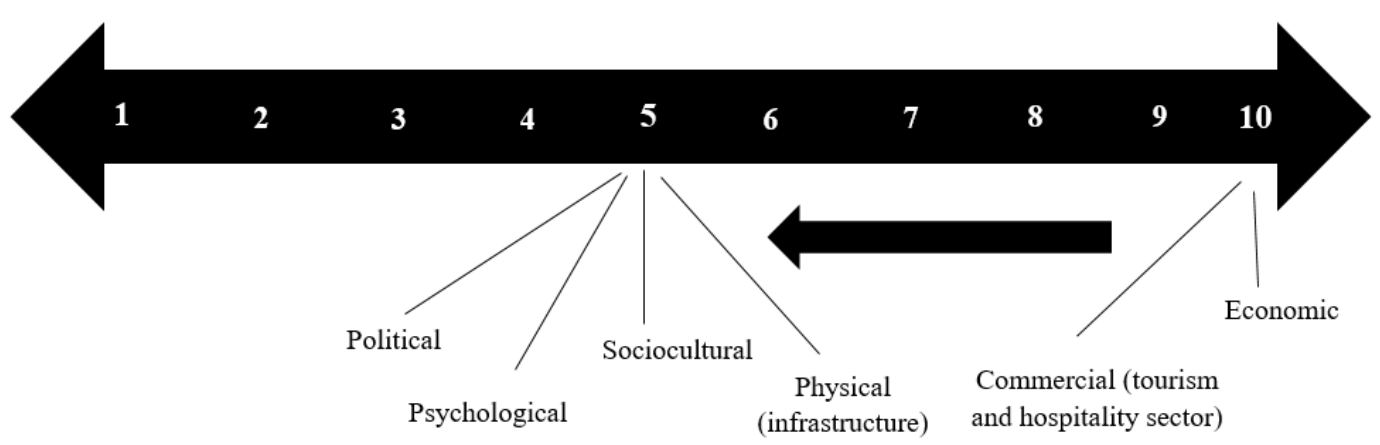

Fig. 2. Strength of a type of impact

Having reviewed Figure 2, it can be seen that the strongest evaluated impact in cultural tourism is economic and hospitality (10 out of 10 points), and only then it leads to weaker impacts that do not have a specific point; however, they distribute on a scale of average values from 4 to 7 and include infrastructure, sociocultural, psychological and political. The point is that all the types of impact promote tourism development but the strongest is the economic and hospitality impact.

Impact has measuring levels; therefore, the respondents were asked which measuring level was seen in cultural tourism development and when implementing cultural events. The interested parties responded that cultural events had both positive and negative impact on tourism development and had both direct and indirect impact.

Fig. 3 shows positive impact: Constant feedback, interest of the city's residents" (Expert No. 1); 'international partners' network, advantage in the market because of unique resources" (Expert No. 2); "adding to the budget in order to ensure implementation of further anticipated activities" (Respondent No. 1); "and "education and nurture of formed values in the consciousness of the society, encouragement of cultural consumption in Europe" (Respondent No. 2).

Negative impact: "Negative impact is possible because mistakes are unavoidable when carrying out any event" (Expert No. 1); also, negative impact can manifest due to "high 
concentration of human and financial resources for one event, disposal of budget for non-primary services" (Respondent No. 3) and "an increase in the number of tourists is not always good for city residents who live, for instance in Kaunas
Old Town because their level of living decreases; however, this shows that each sector of commercial tourism in the city has to control and plan cultural tourism" (Expert No. 2).

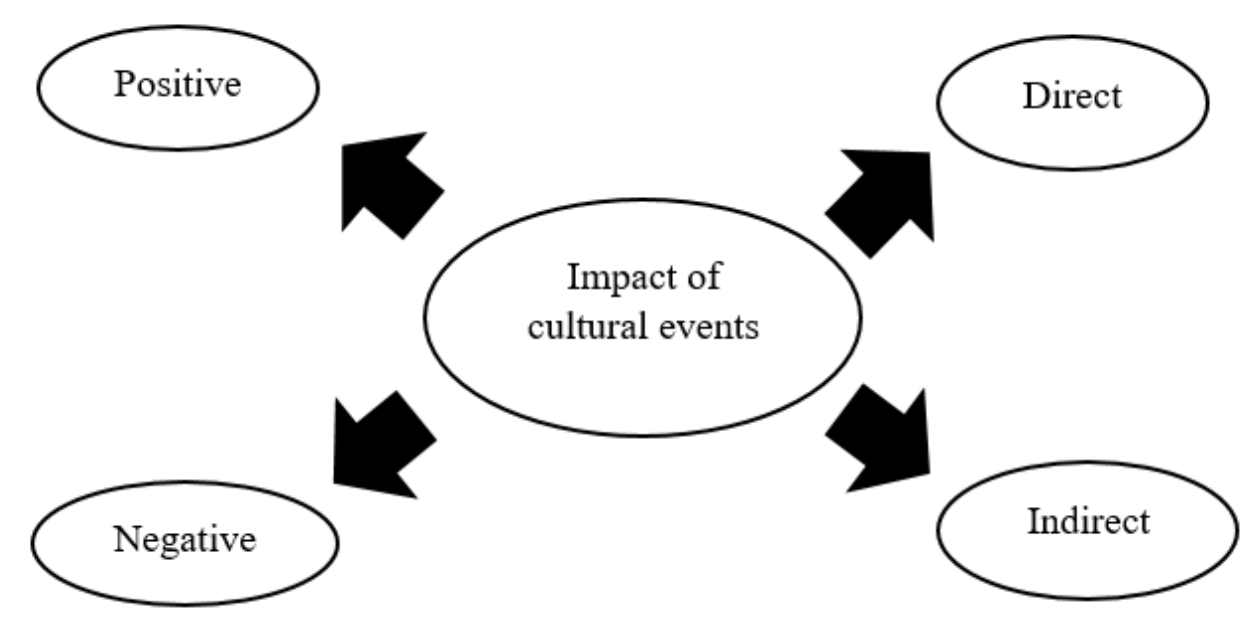

Fig. 3. Positive, negative, direct, indirect impact

Impact can also be direct and indirect. In order to find out how study participants think international and intercultural cooperation when carrying out major cultural events creates direct or indirect impact on cultural tourism development planning in the city, the results showed that impact could be direct and indirect. Experts No. 2 and No. 3 claim that "Implementing cultural, mega events, international and intercultural cooperation has both direct and indirect impact on cultural tourism development because mega events are often prepared when carrying out not only intersectoral, but also international and intercultural cooperation." Respondent No. 3 agrees with the experts and adds, "Thanks to international partners, news about a mega event expands, i.e., activities of interested parties gain advantage in the market due to created international partners." Respondents No. 1, No. 2 and No. 4 claim that direct impact: everything that is clearly noticeable: infrastructural changes, advertising, etc. Experts No. 1 and No. 2 claim that indirect impact: recognition of the city, economic changes (positive), increased tourist flows.

Impact on cultural events on the city also has an effect; respondents' answers on what impacts cultural events have on the city are presented in Figure 4.

Analysing Figure 4, one could look at implementation of cultural events through different sides of interested parties. Experts No. 1 and No. 2 claim, "What is important in the city, for instance, city's government or public sector, is that the infrastructure of hospitality and hotels will surely increase"; Respondent No. 2 agrees with the experts and claims that, "Even now it can be seen that new hotels, new accommodation facilities are being established, new opportunities arise because the market and demand are growing." Expert No. 1 says, "There is a demand for guides or persons who provide other hospitality services." Respondent No. 3 agrees, "New content that attracts new visitors to the city, initiated new hospitality services; we try to create active partnerships with various institutions such as associations of guides or hotels." Expert No. 2 adds, "Implementation and 
developing ideas such as hotel concierge services or cultural taxis expands the package of cultural services that is oriented towards enthusiasts of cultural events". Respondent No. 2 claims, "The city finds it relevant that there are new jobs in the tourism sector". Respondent No.
4 and Expert No. 2 claim, "It can be noted that the title of the European Capital of Culture provides a city with long-term impact for the growth of recognition and the tourism sector because it triggers new partnerships, new services."

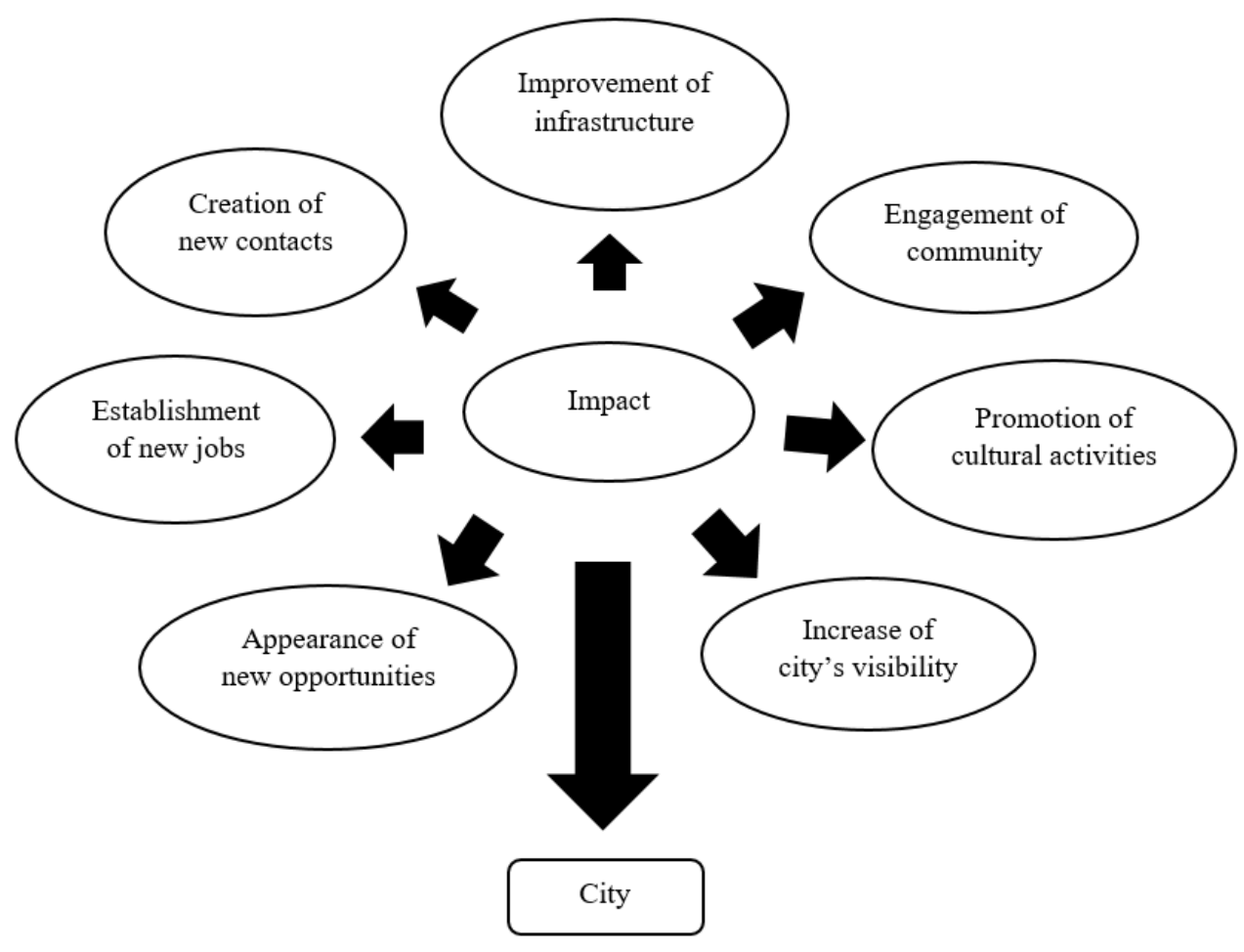

Fig. 4. Impact of cultural events on the city

Therefore, impact is a process that encompasses such types of impact as economic, tourism and hospitality, sociocultural, physical (infrastructure), psychological and political; however, looking from cultural tourism point of view, economic and hospitality types of impact can be felt the most through the impact of cultural events, and only later does it transfer to other types of impact. Thus, cultural tourism displays both negative and positive impact of cultural events because, in terms of positive impact, cultural events make people's interest in the city more active, create new contacts and relations that can open up new partnerships and get feedback after an event, whereas negative impact can arise from local residents who are not always happy with the increased numbers of tourists, especially if they live in the centre of the city or the old town where the flows of tourists are low; in this way, the quality of life of a local resident decreases. Thus, it is important to plan and respectively control tourist flows. As cultural tourism development organises cultural events, direct and indirect impact is caused by international and intercultural cooperation. Also, the impact of cultural events on cultural tourism development planning in the city can have impact on creating new opportunities, improving infrastructure, creating new contacts, increasing the city's visibility, establishing new jobs, encouraging cultural activities and engagement of communities.

\section{CONCLUSIONS}

1. Cultural events are a widely perceived events that describe a service that provides 
visitors with exclusive experiences and satisfies their interests. It is also a factor that provides people with education, improvement, education opportunities through cultural events. It is not only art, cultural heritage or music events because a cultural event can encompass sports and science events. Cultural tourism is the most rapidly developing type of tourism. This type of tourism is mostly related to the goal of experiencing many cultural experiences. It is a trip that is related to a specific goal and it includes participation in cultural events and getting to know a city.

2. The impact of cultural events on the development of cultural tourism is complex because impact is also described as a process that can have an effect on various areas such as economic, physical, tourism and hospitality, sociocultural, political and psychological. Impact can also be measured as the results of certain actions that determine the relations between cause and effect. Impact can have an effect in various ways such as direct or indirect, or have positive and negative consequences. Moreover, impact is important in evaluating the measure of time such as short-term and long-term. All of these impacts created by cultural events have impact on cultural tourism development that are important to analyse in order to avoid negative events.

3. The empirical study shows that the impact of cultural events as a factor of urban cultural tourism development planning encompasses various processes such as planning and development in two axes, i.e., the city and cultural tourism. All these sides interact because the impact of cultural events effects both the city and cultural tourism, and this impact can be different (direct, indirect, long-term, short-term, positive, negative, and it can have an effect on such areas as economic, tourism and hospitality, physical, sociocultural, psychological and political) and provide certain feedback, which has impact on cultural tourism development and its planning.
4. The study shows that according to interested parties, the impact of cultural events as a factor for cultural tourism development planning creates a positive and negative, also a direct and indirect impact, and the strongest types of impact are economic and hospitality (tourism) impact which in its turn encompasses other types of impact such as physical, sociocultural, psychological and political.

5. Study results show that the impact of Kaunas city (Lithuania) cultural events provides cultural tourism development planning with new opportunities, i.e., new international relations, expanded sector of hospitality and business, increase of tourists; however, all this must be planned and controlled in order for Kaunas city and its residents to be protected and avoid negative effects created by the impact of a cultural event. Furthermore, having analysed the impact of cultural events as a factor of cultural tourism development planning when planning cultural tourism development through cultural events raises main problems, it is seen that this still does not involve completely transparent cooperation between actors of culture (event organisers) and the tourism and city sectors; this is manifested through communication made public when there is no clear information on happening events because responsible persons do not provide timely information for the tourism information centre, and the centre cannot transfer it to other interested parties (tourism agencies, travel agencies and hotels, international partners); therefore, tourist interest and flows are lost.

\section{References}

1. Allen, J. et. al. (2005). Festival and special event management. New Baskerville.

2. Andriotis, K. (2000). LOCAL COMMUNITY PERCEPTIONS OF TOURISM AS A DEVELOPMENT TOOL: THE ISLAND OF CRETE. United Kingdom: Bournemouth University.

3. Andriotis, K. (2005). Community Groups' Perceptions of and Preferences to Tourism Development. Evidence from Crete. Journal of Hospitality and Tourism Research, 29(1):67-90. 
4. Armaitienè, A. (2009). Aiškinamasis turizmo terminu žodynas. Vilnius: The Science and Encyclopaedia Publishing Centre.

5. Monitoring Group on Cultural Heritage in the Baltic Sea States. (2009). Kultūros paveldas ir turizmas: galimybès, poveikis, partnerystè ir valdymas. Vilnius: Department of Cultural Heritage under the Ministry of Culture.

6. Baltic Cultural Tourism Policy Paper. (2003). UNESCO.

Access:

https://unesco.It/uploads/file/failai_VEIKLA/kultur a/kulturinis_turizmas/Baltijos_saliu_kulturinio_turi zmo_politikos_dokumentas.pdf [Accessed on 28/03/2019]

7. Bernadette, Q. (2005). Arts Festivals and the City. Urban Studies, 42(5):927-943. Access: https://www.researchgate.net/publication/233870 073_Arts_Festivals_and_the_City [Accessed on 15/03/2019]

8. Bitinas, B., Rupšienè, L., \& Žydžiūnaitè, V. (2008). Kokybinių tyrimų metodologija. Klaipèda.

9. Bowdin, G. et al. (2006). Events Management Second Edition. Oxford: Butterworth-Heinemann is an imprint of Elsevier.

10. Butler, R. W. (2008). The Concept of A Tourist Area Cycle of Evolution: Implications for Management of Resources. Canadian Geographer / Le Géographe canadien, 24(1):5 12.

11. Deffner, A. M., \& Labrianidis, L. (2005). Planning Culture and Time in a Mega-event: Thessaloniki as the European City of Culture in 1997. International Planning Studies, 10(3-4):241-264. Access: http://www.scholars-onbilbao.info/fichas/DeffnetetaltIPS2005.pdf [Accessed on 17/02/2019]

12. Drūteikienè G. et al. (2007). Aukštojo mokslo institucijų jivaizdis: šališki veiksniai. INFORMACIJOS MOKSLAI, 40. Access: http://www.zurnalai.vu.It/informacijosmokslai/article/view/3471/2532 [Access on 18/03/2019]

13. Flew, T. (2014). Creative Cities and Creative Clusters. Creative Articulations: Creative Research Network. Access: https://www.researchgate.net/publication/274644 49 Creative Cities and Creative Clusters[Acce ssed on 22/02/2019]

14. Getz, D. (2008). Event tourism: Definition, evolution and research. Tourism Management, (29):03:428.

Access: https://www.sciencedirect.com/science/article/pii/ S0261517707001719 [Accessed on 15/03/2019]
15. Guzauskas, A. (2011). Renginių organizavimas: metodinè medžiaga studentams ir renginių organizatoriams. Kaunas: Vitae Litera.

16. Ivanauskaitè, A. (2015). MIESTO URBANISTINĖS FORMOS SAMPRATA IR JOS TAIKYMO GALIMYBÉS LIETUVOJE. SCIENCE FUTURE OF LITHUANIA, 7(1):46-54. Access: https://journals.vgtu.It/index.php/MLA/article/dow nload/2624/2137 [Accessed on 18/03/2019]

17. Jackson, A., \& Kidd, J. (2011). Perfoming heritage: Research, practice and innovation in museum theatre and live interpretation. Oxford Road: Manchester University Press.

18. Jurènienè V. (2009). Kultūrinis turizmas. Kultūros vadyba (ed. J. Svičiuliene) I.Vilnius: Vilnius University publishing house.

19. Jurènienè, V., \& Urbonienè, A. (2018). KULTÜROS CENTRAI: bendradarbiavimas, bendruomenių mobilizavimas ir edukacinės praktikos. Vilnius: Vilnius University.

20. Kardelis, K. (2002). Mokslinių tyrimy metodologija ir metodai. Kaunas: JUDEX publishing house.

21. Kunzmann, K. R. (2004). Culture, creativity and special planning. TPR, (4):75. Access: http://www.scholars-on-

bilbao.info/fichas/KUNZMANN\%20CultureCreativ itySpatialPlanningTPR2004.pdf [Accessed on 21/02/2019]

22. Seimas of the Republic of Lithuania. (1998). Law on Tourism of the Republic of Lithuania. Official Gazette. Access: https://eseimas.Irs.It/portal/legalAct//t/TAP/313f8d0079da 11e89188e16a6495e98c [Accessed on 05/03/2019]

23. Government of the Republic of Lithuania. (2014). Lithuanian Tourism Development Programme 2014-2020. TAR, No. 3262.

24. Lopa, J. M., \& Marecki, R. F. (1999). The critical role of quality in the tourism system. ProQuest Science Journals, 37-42.

25. Marozienè, I. (2010). Darnaus turizmo planavimo modelis. Vilnius.

26. Maughan, C., \& Franco, B. (2004). THE ECONOMIC AND SOCIAL IMPACT OF CULTURAL FESTIVALS IN THE EAST MIDLANDS OF ENGLAND. De Montfort University, Leicester. Access: https://static.an.co.uk/wp-content/uploads/2016/09/Economicand-social-impact-final-report.pdf [Accessed on 18/03/2019]

27. McCarthy, J. (2005). Promoting Image and Identity in 'Cultural Quarters': the Case of Dundee. Local Economy, 20(3):280-293. Access: 
https://www.researchgate.net/publication/247513 881_Promoting_Image_and_Identity_in_'Cultural Quarters'_the_Case_of_Dundee [Accessed on 21/02/2019]

28. McCartney, G., \& Osti, L. (2007). From Cultural Events to Sport Events: A Case Study of Cultural Authenticity in the Dragon Boat Races. Journal of Sport Tourism , 12(1):25-40. Access: https://www.researchgate.net/publication/249022 154_From_Cultural_Events_to_Sport_Events_A _Case_Study_of_Cultural_Authenticity_in_the_D ragon_Boat_Races [Accessed on 15/03/2019]

29. Naumov, N. (2016). Cultural Tourism. EJTHR, 7(1):72-73.

30. Novelskaitè, A. (2012). Socialinio tyrimo terminija: tyrimo strategija, tyrimo planas, tyrimo dizainas, tyrimo procesas. Vilnius .

31. QIN, B., \& Zhang, Y. (2014). Note on urbanization in China: Urban definitions and census data. China Economic Rewiev, 495-502. Access: https://www.sciencedirect.com/journal/chinaeconomic-review [Accessed on 22/02/2019]

32. Quinn, B. (2009). Festivals, events and tourism. Dublin: Dublin Institute of Technology.

33. Richards, G. (2018). What is Cultural Tourism? Nationaal Contact Monumenten, 1-16.

34. Richards, G., \& llie, R. (2013). THE IMPACT OF CULTURAL EVENTS ON TOURISM DEVELOPMENT: SIBIU - THE EUROPEAN CULTURAL CAPITAL. University of Târgu Jiu, Economy Series, (1):6-12. Access: https://www.academia.edu/7945405/THE_IMPA CT_OF_CULTURAL_EVENTS_ON_TOURISM_ DEVELOPMENT_SIBIU_-

THE_EUROPEAN_CULTURAL_CAPITAL

[Accessed on 05/03/2019]

35. Richards, G., \& Rotaru, I. (2004). The Impact of Cultural Events on City Image: Rotterdam, Cultural Capital of Europe 2001. Urban Studies, (10):41. Access: http://citeseerx.ist.psu.edu/viewdoc/download?do $\mathrm{i}=10.1 \cdot 1.476 .3943 \&$ rep $=$ rep $1 \&$ type $=p d f$

[Accessed on 15/03/2019]

36. Ritchie, J. R. (1984). Assessing the Impact of Hallmark Events: Conceptual and Research Issues. In Journal of Travel Research, 23(1):2-11.

37. Rukužienè, R. (2017). LIETUVOS TURIZMO KLASTERIŲ PLĖTROS PERSPEKTYVOS. Regional FoRmation and development StudieS, (3):23. Access: http://journals.ku.It/index.php/RFDS/article/view/1 589 [Accessed on 18/03/2019]
38. Sayyman, M., \& Sayyman, A. (2004). Economic impact of cultural events. SAJEMS NS7, (4):629.

39. Sassen, S. (2005). The Global City: introducing a Concept. WINTER/SPRING, 11(2):27-43. Access:

http://www.saskiasassen.com/pdfs/publications/t he-global-city-brown.pdf [Accessed on 18/02/2019]

40. Simanavičius, A., \& Simanavičienè, Ž. (2012). TURIZMO RIZIKOS SPECIFINIAI BRUOŽAI. ECONOMICS AND MANAGEMENT, 17(2):578584.

41. Sinkienè, J. (2008). Miesto konkurencingumo veiksniai. VIEŠOJI POLITIKA IR ADMINISTRAVIMAS, $25 . \quad$ Access: https://www.mruni.eu/upload/iblock/5f7/8_j.sinkie ne.pdf [Accessed on 20/03/2019]

42. Skoultsos, S. G., \& Tsartas, P. (2009). EVENT TOURISM: STATEMENTS AND QUESTIONS ABOUT ITS IMPACTS ON RURAL AREAS. TOURISMOS: $\quad$ AN INTERNATIONAL MULTIDISCIPLINARY JOURNAL OF TOURISM, 4(4):293:310. Access: https://www.researchgate.net/publication/476972 70_Event_tourism_Statements_and_questions_ about_its_impacts_on_rural_areas [Accessed on 22/02/2019]

43. Smith, A., \& Fox, T. (2007). From 'Event-led' to 'Event-themed' Regeneration: The 2002 Commonwealth Games Legacy Programme. Urban Studies, 44(5):1125-1143. Access: https://www.researchgate.net/publication/239773 696_From_'Event-led'_to_'Event-

themed'_Regeneration_The_2002_Commonweal th_Games_Legacy_Programme [Access on 18/03/2019]

44. Streimikiene, D., \& Bilan, Y. (2015). REVIEW OF RURAL TOURISM DEVELOPMENT THEORIES. Transformations in Business \& Economics, 2(35):21-34. Access: Access: http://www.transformations.knf.vu.It/35/ge35.pdf [Accessed on 05/03/2019]

45. Ščiglienè, V. (2014). KULTŪRINIO TURIZMO SRITYS IR JỤ YPATUMAI: KÜRYBINGOS VEIKLOS MODELIAI. ACTA ACADEMIAE ARTIUM VILNENSIS, (72):141-157.

46. Ščiglienè, V. (2017). Kultūra, menas ir Kultūrinis turizmas: ar savaime suprantamos jungtys? Regional Formation and Development Studies, (3):23. Access: http://journals.ku.lt/index.php/RFDS/article/view/1 593 [Access on 18/03/2019]

47. Tidikis, R. (2003). Socialiniy moksly tyrimy metodologija. Vilnius.

Https://escipub.com/international-journal-of-social-research/ 
48. Turner, R. K. (2003). Sustainable Environmental Economics and Management: Principles and Practice. London.

49. Valantiejus, A. (2007). leškant sociologijos metodo. Georgas Simmelis ir didmiesčio tikrovès ribos. Sociologija. Mintis ir veiksmas, (1):19. Access: http://www.zurnalai.vu.It/sociologijamintis-ir-veiksmas/article/view/6031/4939 [Accessed on 20/03/2019]

50. State Tourism Department. (2006). TURIZMO PLÉTROS PLANAVIMO DOKUMENTŲ, PROGRAMŲ, GALIMYBIỤ STUDIJŲ RENGIMO IR JỤ IGYVENDINIMO STEBÉSENOS METODINĖS REKOMENDACIJOS. No. V-94.

51. Vilnius University. (2008). KULTŪROS INDUSTRIJOS: iššūkiai ir persperktyvos. Vilnius: Vilnius University publishing house.

52. Vilnius University. (2009). Kultūros vadyba II. Vilnius: Vilnius University publishing house.

53. Vilnius University. (2011). Kultūra ir Miestas. Vilnius: Vilnius University publishing house.

54. Wachsmuth, D. (2014). City as ideology: reconciling the explosion of the city form with the tenacity of the city concept. Environment and Planning D: Society and Space, (31):75-90. Access:

https://journals.sagepub.com/doi/10.1068/d2191 1 [Accessed on 18/03/2019]

55. Žilinskas, V. J. (2011). TURIZMO SOCIOKULTÜRINIO POVEIKIO AKTUALIJOS. Management theory and studies for rural business and infrastructure, (1):25. Access: http://vadyba.asu.lt/25/271.pdf [Accessed on 18/03/2019] 